\title{
Analisis Model Altman Z-Score, Springate, dan Zmijewski sebagai Metode dalam Memprediksi Kondisi Kebangkrutan pada PT. Garuda Indonesia, Tbk Periode 2014-2018
}

\author{
Desyah Natalia Bilondatu ${ }^{1}$ \\ Meriyana Franssisca Dungga ${ }^{2}$ \\ Selvi ${ }^{3}$ \\ Fakultas Ekonomi, Universitas Negeri Gorontalo \\ selvi@ung.ac.id
}

\begin{abstract}
This study aims to find out, describe and explain the results of the application of analysis from the prediction method of bankruptcy of the Altman Z-Score, Springate, and Zmijewski models used in assessing and predicting the potential for bankruptcy with the object of research at PT. Garuda Indonesia (Persero) Tbk 2014-2018. The method used in this research is descriptive research method using a quantitative approach, and the operationalization of the variables used is the independent variable, namely the bankruptcy prediction model with the dependent variable is financial ratios. The data used are secondary data in the form of annual financial reports (annual reports) PT. Garuda Indonesia (Persero) Tbk for the period 2014 to 2018. The results of this study indicate that the Altman Z-Score, Springate and Zmijewski methods are able to measure and predict bankruptcy of companies with different portions according to the calculations applied in each of these analyzes.
\end{abstract}

Keywords : Altman Z-Score, Springate, Zmijewski, and Bankruptcy

\begin{abstract}
Abstrak
Penelitian ini bertujuan untuk mengetahui, menggambarkan dan menjelaskan hasil penerapan analisis dari metode prediksi kebangkrutan model Altman Z-Score, Springate, dan Zmijewski yang digunakan dalam menilai dan memprediksi potensi kebangkrutan dengan objek penelitian di PT. Garuda Indonesia (Persero) Tbk 2014-2018. Metode yang digunakan dalam penelitian ini adalah metode penelitian deskriptif dengan menggunakan pendekatan kuantitatif, dan operasionalisasi variabel yang digunakan adalah variabel bebas, yaitu model prediksi kebangkrutan dengan variabel terikat adalah rasio keuangan. Data yang digunakan adalah data sekunder berupa laporan keuangan tahunan (laporan tahunan) PT. Garuda Indonesia (Persero) Tbk untuk periode 2014 hingga 2018. Hasil penelitian ini menunjukkan bahwa metode Altman ZScore, Springate dan Zmijewski mampu mengukur dan memprediksi kebangkrutan perusahaan dengan porsi yang berbeda sesuai dengan perhitungan yang diterapkan di masing-masing analisis ini.
\end{abstract}

Kata Kunci : Altman Z-Score, Springate, Zmijewski, dan Kebangkrutan 


\section{PENDAHULUAN}

Sektor transportasi merupakan salah satu industri jasa yang paling banyak dibutuhkan oleh masyarakat sebagai sarana penghubung jarak jauh antara tempat satu dengan tempat lainnya dengan cepat dan mudah, salah satunya transportasi udara (pesawat terbang). Pertumbuhan sektor transportasi udara akan mencerminkan pertumbuhan ekonomi secara langsung sehingga transportasi udara mempunyai peranan yang penting dan strategis, baik secara makro maupun mikro.

Dewasa ini, perkembangan dan pertumbuhan sektor transportasi udara tersebut tidak lepas dari peningkatan jumlah pengguna jasa penerbangan, dilihat dari beberapa alasan yang di antaranya adalah adanya kepentingan bisnis, adanya kepentingan pariwisata, efektifitas waktu perjalanan dan berbagai urusan lainnya. Indonesia sendiri merupakan negara dengan geografis yang berbentuk kepulauan dan terbentang sepanjang garis Khatulistiwa dari Sabang sampai Merauke seluas $1,9 \mathrm{~km}$ persegi dengan potensi pariwisata yang sangat menjanjikan dan sering kali menjadi sorotan dunia, dan untuk kemudahan dalam mengakses tempat wisata tersebut, transportasi udara (pesawat terbang) adalah pilihan yang banyak diminati oleh wisatawan asing maupun lokal dikarenakan transportasi udara dianggap lebih cepat untuk mengantarkan para wisatawan ke tempat tujuannya, ini terlihat dengan banyaknya maskapai penerbangan yang melayani rute penerbangan baik nasional maupun internasional.

Selain itu jasa penerbangan merupakan suatu kegiatan transportasi yang menggunakan teknologi tinggi, keamanan serta kenyamanan, sehingga pada saat ini penggunaan jasa penerbangan masih menjadi pilihan utama masyarakat dalam pemenuhan kebutuhan transportasi jarak jauh (dalam hal ini rute dalam negeri maupun rute luar negeri). Namun dibalik pertumbuhan pasar yang sangat menjanjikan tersebut, tidak dapat dipungkiri persaingan di dunia penerbangan memang ketat terutama masalah pelayanan dan fasilitas maskapai.

Sebagian maskapai Indonesia ada yang berhasil memperluas penerbangan hingga mancanegara dan memperbaharui semua fasilitas yang dibutuhkan, namun sebagian lagi harus gulung tikar (bangkrut) dengan beberapa alasan, selain itu pendapatan yang juga tak sebanding dengan biaya yang dikeluarkan menyebabkan beberapa maskapai domestik harus memikirkan kembali tarif tiket pesawat. Sebelumnya, di tahun 2018 publik telah digegerkan dengan kenaikan harga tiket penerbangan domestik yang tiba-tiba meroket tinggi.

Indonesia National Air Carrier Association (INACA) mengakui adanya kenaikan harga tiket pesawat sebesar 40 persen sampai 120 persen beberapa waktu terakhir, kenaikan itu terjadi sejak November tahun 2018 lalu. INACA mengisyaratkan bahwa pelemahan nilai tukar rupiah terhadap dolar Amerika Serikat sepanjang tahun 2018 lalu telah menjadi salah satu faktor yang menyebabkan maskapai penerbangan sulit meraup keuntungan yang dikhawatirkan akan sangat berdampak pada sistem kinerja dan kesehatan keuangan peerusahaan sehingga maskapai penerbangan harus segera mengambil tindakan seperti menaikkan harga tiket pesawat.

RTI Infokom mencatat rupiah sempat bertengger di level Rp15.200 per dolar Amerika Serikat tahun 2018 lalu. Ketika rupiah tunduk pada mata uang AS, biaya operasional yang dikeluarkan oleh perusahaan penerbangan menjadi lebih besar. Seperti, pembelian bahan 
bakar (avtur) yang harganya sudah naik 165 persen sejak tahun 2016 lalu, pembayaran kredit pembelian pesawat kepada perusahaan pembiayaan dan Pajak Pertambahan Nilai (PPN) yang ditanggung oleh penerbangan domestik. Faktor-faktor itulah yang menggerus pendapatan bersih maskapai yang menyebabkan harga tiket pesawat domestik menjadi lebih mahal ketimbang penerbangan internasional. Saat ini, mereka hanya bisa mengantongi pendapatan bersih sebesar satu sampai dua persen yang seharusnya, maskapai internasional bisa mengantongi hingga tiga persen. (sumber dilansir dari liputan6.com)

Terlepas dari itu beberapa perusahaan transportasi udara yang ada di Indonesia telah menjadi sorotan utama para analisis ekonomi saat ini, maskapai-maskapai penerbangan ini tidak terkecuali Garuda Indonesia yang saat ini paling dikhawatirkan akan mengalami dampak dari kondisi perekonomian Indonesia yang sampai saat ini masih belum menentu dan mengakibatkan tingginya risiko suatu perusahaan yang sedang mengalami kesulitan keuangan atau bahkan kebangkrutan.

Oleh karenanya, diperlukan suatu analisis prediksi kebangkrutan untuk mengukur tingkat kesehatan keuangan suatu perusahaan yang dapat dijadikan sebagai peringatan awal bagi perusahaan jika perusahaan tersebut berada pada titik financial distress, ini bertujuan untuk menghindari serta mengantisipasi terjadinya kebangkrutan perusahaan pada masa yang akan datang. Hal tersebut akan sangat membantu berbagai pihak seperti pemegang saham, investor, pemerintah, akuntan dan manajemen perusahaan yang bersangkutan untuk memperoleh informasi mengenai seberapa besar perusahaan dapat bertahan atau seberapa besar prediksi kebangkrutannya. Informasi tersebut bisa didapatkan melalui laporan keuangan perusahaan yang dijadikan sebagai dasar penilaian.

Berbagai model analisis kebangkrutan telah dikembangkan untuk memprediksikan awal kebangkrutan perusahaan, seperti model Altman Z-Score yang dikembangkan pada tahun 1968 oleh Edward I. Altman, model Springate yang dikembangkan pada tahun 1978 oleh Gorgon L.V.Springate, dan model Zmijewski pada tahun 1983 yang dihasilkan dari riset Zmijewski selama dua puluh tahun berulang. Model-model analisis tersebut menggunakan variabel-variabel rasio keuangan untuk memprediksi kebangkrutan perusahaan, dilakukan dengan menganalisa laporan keuangan suatu perusahaan dua hingga lima tahun sebelum perusahaan tersebut akan diprediksi dan pada akhirnya perusahaan akan diklasifikasikan berada dalam zona aman dari kebangkrutan atau terancam bangkrut.

Berdasarkan uraian latar belakang tersebut, peneliti tertarik untuk mengangkat dan meneliti masalah ini dengan mengambil judul "Analisis Model Altman Z-Score, Springate, Dan Zmijewski Sebagai Metode Dalam Memprediksi Kondisi Kebangkrutan Pada PT. Garuda Indonesia (Persero) Tbk Periode 2014-2018".

\section{KAJIAN PUSTAKA}

Menurut Harjito dan Martono (2014:51-52) Laporan keuangan (financial statement) merupakan ikhtisar mengenai keadaan keuangan suatu perusahaan pada suatu saat tertentu. Laporan keuangan secara garis besar dibedakan menjadi 4 macam yaitu laporan neraca, laporan laba-rugi, laporan perubahan modal dan laporan aliran kas. Dari keempat laporan keuangan tersebut dapat diringkas lagi menjadi 2 macam yakni neraca dan laporan laba-rugi saja. Hal ini dikarenakan laporan perubahan modal dan laporan aliran kas pada akhirnya akan diikhtisarkan dalam neraca dan laporan laba-rugi.

http://jurnal.stiekma.ac.id/index.php/JAMIN 


\section{A. Analisis Laporan Keuangan}

Menurut Munawir (2010:36), ada dua metode analisis yang digunakan oleh setiap penganalisis laporan keuangan, yaitu analisis horisontal dan analisis vertikal. Analisis horisontal adalah analisis dengan mengadakan perbandingan laporan keuangan untuk beberapa periode atau beberapa saat sehingga akan diketahui perkembangannya.

\section{B. Kebangkrutan}

Kebangkrutan bisa diartikan sebagai suatu kegagalan yang terjadi dalam perusahaan. Pengertian Kebangkrutan (bankruptcy) di Indonesia mengacu pada UndangUndang No. 37 tahun 2004 tentang Kepailitan dan Penundaan atas Pembayaran Hutang, yang menyebutkan:

1. Debitur yang mempunyai dua atau lebih kreditur dan tidak membayar sedikitnya satu utang yang telah jatuh waktu dan tidak dapat ditagih, dinyatakan pailit dengan putusan pengadilan yang berwenang baik atas permohonannya sendiri, maupun atas permintaan seorang atau lebih krediturnya.

2. Permohonan sebagaimana disebut dalam butir di atas, dapat juga diajukan oleh kejaksaan untuk kepentingan umum.

Menurut Rudianto (2013:251) Kebangkrutan adalah ketidakmampuan perusahaan untuk membayar kewajiban keuangannya pada saat jatuh tempo yang menyebabkan kebangkrutan atau kesulitan likuiditas yang mungkin sebagai awal kebangkrutan.

\section{Analisis Kebangkrutan}

Analisis kebangkrutan sangat bermanfaat karena kebangkrutan bisa membuat perusahaan melakukan antisipasi yang diperlukan. Biasanya kebangkrutan yang relative tinggi dihindari atau diminimisasi. Indikator kebangkrutan dapat dilihat dari analisis aliran kas, analisis strategi perusahaan, sampai laporan keuangan perusahaan serta lembaga rating sebagai sumber eksternal informasi kebangkrutan. Prediksi kebangkrutan bisa dilakukan dengan menghitung rasio-rasio keuangan yang menggunakan data beberapa periode sebelum kebangkrutan.

Terdapat berbagai teknik analisis, seperti model Altman Z-Score (1968), model Springate (1978), dan model Zmijewski (1983). Model-model analisis ini dapat dipergunakan untuk melakukan penilaian kinerja sebuah perusahaan. Akan tetapi, perlu disadari bahwa teknik atau metode analisis yang berbeda akan sesuai untuk tujuan yang berbeda sesuai kebutuhan.

\section{Analisis Model Altman Z-Score}

Model Altman Z-Score adalah salah satu model analisis dalam memprediksikan kebangkrutan suatu perusahaan yang diperkenalkan oleh Edward I. Altman pada penelitiannya ditahun 1968, Altman merupakan orang pertama yang menerapkan Multiple Discriminant Analysis (MDA).

Altman menyadari pada penelitiannya bahwa tidak semua perusahaan sudah go public dan tidak mempunyai nilai pasar, maka dari itu Altman mengembangkan model di atas dengan menggantikan variabel X4 pada penelitiannya ditahun 1984, sehingga model tersebut dapat digunakan untuk perusahaan go public maupun non public. 
Model tersebut dinamakan sebagai model Altman (Z-Score) Revisi dengan menghasilkan formula sebagai berikut:

$$
Z=0,717 X_{1}+0,847 X_{2}+3,107 x_{3}+0,420 x_{4}+0,998 x_{5}
$$

Sumber: Hanafi (2016:170)

Dimana:

$\mathrm{X}_{1}=$ Modal Kerja/Total aset

$\mathrm{X}_{2}=$ Laba yang ditahan/Total aset

$X_{3}=$ Laba sebelum bunga dan pajak/Total aset

$\mathrm{X}_{4}=$ Nilai buku saham biasa dan preferen/Nilai buku total utang

$X_{5}=$ Penjualan/Total aset

Hanafi (2016:273) setuju bahwa model revisi tersebut mempunyai kemampuan prediksi yang cukup baik juga dengan menghasilkan tingkat prediksi 94 persen benar dari total sampel, sedangkan model yang asli menghasilkan tingkat prediksi 95 persen benar dari total sampel yang diambil.

Altman menjelaskan, bahwa jika nilai $Z$ suatu perusahaan lebih besar dari 2,9 maka dapat disimpulkan bahwa perusahaan sehat dan tidak mengalami kesulitan keuangan. Sebaliknya, jika nilai Z lebih kecil dari nilai 1,2 maka dapat diprediksikan bahwa perusahaan memiliki kesulitan keuangan yang sangat besar dan berisiko tinggi sehingga kemungkinan bangkrutnya sangat besar.

Namun, apabila nilai Z perusahaan tidak lebih dari 2,9 dan tidak kurang dari 1,2 perusahaan dapatdikategorikan ke daerah abu-abu yang artinya perusahaan memiliki kesulitan keuangan, namun belum bisa dipastikan kemungkinan terselamatkan dan kemungkinan bangkrut sama besarnya.

\section{E. Analisis Model Springate}

Menurut Rudianto (2013:262) Springate adalah model analisis untuk memprediksi keberlangsungan hidup suatu perusahaan dengan mengkombinasikan beberapa rasio keuangan yang umum dengan diberikan bobot yang berbeda satu dengan lainnya.

Springate merupakan metode yang ditemukan oleh Gordon L.V Springate pada tahun 1978. Dengan mengikuti prosedur yang dikembangkan Altman, Springate mengambil 40 perusahaan sebagai sampel step-wise multiple discriminate analysis dengan menggunakan 4 dari 19 rasio keuangan yang paling berkontribusi terhadap prediksi kebangkrutan perusahaan sehingga terbentuklah suatu formula yang disebut dengan Springate S-Score dan menentukan batasan (standar) berupa bobot nilai yang berbeda di setiap porsinya untuk memprediksikan kondisi perusahaan apakah berpotensi bangkrut atau tidak bangkrut (dapat dinyatakan sehat). 
Metode Springate ini dapat digunakan untuk memprediksi kebangkrutan dengan tingkat keakuratan 92,5 persen dengan menggunakan rumus sebagai berikut:

$$
S=1,03 X_{1}+3,07 X_{2}+0,66 X_{3}+0,4 X_{4}
$$

Sumber: Rudianto (2013:262)

Dimana:

$$
\begin{aligned}
& X_{1}=\text { Modal Kerja/Total aset } \\
& X_{2}=\text { Laba sebelum bunga dan pajak/Total aset } \\
& X_{3}=\text { Laba sebelum pajak/Hutang lancar } \\
& X_{4}=\text { Penjualan/Total Aset }
\end{aligned}
$$

Springate menjelaskan nilai titik cut-off yang berlaku untuk formula di atas adalah 0,862 yang diklasifikasikan ke dalam dua kategori dimana jika nilai S lebih besar dari 0,862 maka perusahaan dapat dikatakan sehat dan tidak berpotensi bangkrut. Namun, jika nilai $S$ lebih kecil dari 0,862 maka perusahaan dapat diklasifikasikan ke dalam kategori financial distress dan berpotensi bangkrut.

\section{F. Analisis Model Zmijewski}

Analisis yang dihasilkan oleh Zmijewski pada tahun 1983 ini merupakan riset selama 20 tahun. Zmijewski mengambil sampel dengan menggunakan 75 perusahaan bangkrut dan 73 perusahaan sehat selama tahun 1972 sampai dengan tahun 1978 .

Menurut Rudianto (2013:264) Zmijewski adalah metode penilaian kesehatan dan keberlangsungan usaha perusahaan dengan menggunakan 3 rasio keuangan yang kemudian diolah dengan formula dengan tingkat akurasinya sebesar 94,9 persen yang dikenal dengan Zmijewski X-Score yang dapat dilihat dalam rumus berikut:

$$
X=-4,3-4,5 X_{1}+5,7 X_{2}+0,004 X_{3}
$$

Sumber: Rudianto (2013:262)

$$
\text { Dimana: } \begin{aligned}
\mathrm{X}_{1} & =\mathrm{ROA}(\text { Return On Asset) } \\
\mathrm{X}_{2} & =\text { Debt Ratio } \\
\mathrm{X}_{3} & =\text { Current Ratio }
\end{aligned}
$$

Nilai cut-off yang ditetapkan dalam analisis ini adalah 0 (nol) dimana jika nilai $X$ lebih besar atau sama dengan 0 maka perusahaan diprediksikan tidak mengalami ancaman kebangkrutan, sebaliknya jika lebih kecil dari 0 itu menandakan kondisi perusahaan berpotensi mengalami kebangkrutan. 


\section{METODE}

Penelitian ini merupakan penelitian deskriptif dengan menggunakan pendekatan kuantitatif. Data yang digunakan dalam penulisan penelitian ini adalah data sekunder yang berupa laporan keuangan tahunan (annual report) PT. Garuda Indonesia (Persero) Tbk periode 2014 sampai dengan 2018 yang telah diaudit oleh auditor akuntan publik Yng independen dan dipublikasikan di Bursa Efek Indonesia (BEI). Dalam penelitian ini terdapat dua variabel yakni variabel Independen (variabel bebas) dan variabel dependen (variabel terikat) yang digunakan pada model-model prediksi financial distress yang telah dikembangkan sebelumnya, yaitu model Altman (Z-Score), Springate (S-Score), dan Zmijewski (X-Score). Pada penelitian ini, tidak diperlukan uji hipotesis karena penelitian ini hanya perlu mengimplementasikan rumus Altman (Z-Score), Springate (S-Score), dan Zmijewksy (X-Score) sebagai analisis data untuk memprediksikan potensi kebangkrutan perusahaan. Sehubungan dengan masalah yang dikemukakan sebelumnya, maka akan dilakukan analisa berdasarkan data yang diperoleh.

\section{HASIL DAN PEMBAHASAN}

\section{A. Hasil Analisis Data}

\section{Analisis Model Kebangkrutan}

Hasil dari penelitian ini berupa perhitungan dari seluruh rasio-rasio dengan mengolah data berupa laporan keuangan tahunan pada PT Garuda Indonesia Tbk periode 2014 sampai dengan 2018, dimana penelitian ini mengimplementasikan tiga model analisis kebangkrutan yaitu analisis Altman Z-Score yang mengidentifikasikannya ke dalam lima variabel bebas yang digunakan dalam formulanya, analisis Springate dengan menggunakan empat variabel bebas dan analisis Zmijewski dengan memasukan tiga variabel bebas ke dalam formulanya.

Variabel-variabel bebas tersebut kemudian dikalikan dengan bobot koefisien dari masing-masing rasio dalam rumus perhitungan Z-Score revisi, S-Score dan X-Score sebagai berikut:

Formula Altman :

$$
\begin{aligned}
& {\left[Z=0,717 X_{1}+0,847 X_{2}+3,107 X_{3}+0,420 X_{4}+0,998 X_{5}\right]} \\
& \text { Formula Springate : } \\
& {\left[S=1,03 X_{1}+3,07 X_{2}+0,66 X_{3}+0,4 X_{4}\right]} \\
& \quad \text { Formula Zmijewski: } \\
& {\left[X=-4,3-4,5 X_{1}+5,7 X_{2}+0,004 X_{3}\right]}
\end{aligned}
$$

Berikut adalah tabel-tabel yang menyajikan perhitungan model Altman, Springate dan Zmijewski: 
Tabel 1. Overall Indeks Model Prediksi Altman Z-Score PT Garuda Indonesia, Tbk

\begin{tabular}{|l|l|l|l|l|l|l|}
\hline Variabel & Koefisien & $\mathbf{2 0 1 4}$ & $\mathbf{2 0 1 5}$ & $\mathbf{2 0 1 6}$ & $\mathbf{2 0 1 7}$ & $\mathbf{2 0 1 8}$ \\
\hline X1 & 0,717 & $-0,094$ & $-0,041$ & $-0,076$ & $-0,178$ & $-0,179$ \\
\hline X2 & 0,847 & $-0,078$ & $-0,055$ & $-0,049$ & $-0,100$ & $-0,079$ \\
\hline X3 & 3,107 & $-0,394$ & 0,158 & 0,082 & $-0,063$ & 0,072 \\
\hline X4 & 0,420 & 0,165 & 0,169 & 0,156 & 0,139 & 0,110 \\
\hline X5 & 0,998 & 1,261 & 1,150 & 1,032 & 1,108 & 0,998 \\
\hline Z-Score & & $\mathbf{0 , 8 5 9}$ & $\mathbf{1 , 3 8 2}$ & $\mathbf{1 , 1 4 4}$ & $\mathbf{0 , 9 0 6}$ & $\mathbf{0 , 9 2 2}$ \\
\hline
\end{tabular}

Sumber: data sekunder yang diolah kembali oleh penulis

Tabel 2. Overall Indeks Model Prediksi Springate S-Score PT Garuda Indonesia, Tbk

\begin{tabular}{|l|l|l|l|l|l|l|}
\hline Variable & Koefisien & $\mathbf{2 0 1 4}$ & $\mathbf{2 0 1 5}$ & $\mathbf{2 0 1 6}$ & $\mathbf{2 0 1 7}$ & $\mathbf{2 0 1 8}$ \\
\hline X1 & 1,03 & $-0,1353$ & $-0,0585$ & $-0,1098$ & $-0,2559$ & $-0,2578$ \\
\hline $\mathbf{X 2}$ & 3,07 & $-0,3898$ & 0,1565 & 0,0814 & $-0,0621$ & 0,0708 \\
\hline $\mathbf{X 3}$ & 0,66 & $-0,2471$ & 0,0589 & 0,0075 & $-0,0543$ & 0,0051 \\
\hline X4 & 0,4 & 0,5054 & 0,4610 & 0,4135 & 0,4440 & 0,4001 \\
\hline S-Score & & $\mathbf{- 0 , 2 6 6 7}$ & $\mathbf{0 , 6 1 7 9}$ & $\mathbf{0 , 3 9 2 6}$ & $\mathbf{0 , 0 7 1 6}$ & $\mathbf{0 , 2 1 8 3}$ \\
\hline
\end{tabular}

Sumber: data sekunder yang diolah kembali oleh penulis

Tabel 3. Overall Indeks Model Prediksi Zmijewski X-Score PT Garuda Indonesia, Tbk

\begin{tabular}{|l|l|l|l|l|l|l|}
\hline Variabel & Koefisien & $\mathbf{2 0 1 4}$ & $\mathbf{2 0 1 5}$ & $\mathbf{2 0 1 6}$ & $\mathbf{2 0 1 7}$ & $\mathbf{2 0 1 8}$ \\
\hline & $-4,3$ & & & & & \\
\hline ROA & 4,5 & $-0,119$ & 0,024 & 0,003 & $-0,057$ & 0,001 \\
\hline Debt Ratio & 5,7 & 0,717 & 0,713 & 0,730 & 0,751 & 0,792 \\
\hline Cur. Ratio & 0,004 & 0,665 & 0,843 & 0,745 & 0,513 & 0,554 \\
\hline Perubahan & $-4,3$ & $-4,3$ & $-4,3$ & $-4,3$ & $-4,3$ \\
\hline Variabel & $-0,533$ & 0,106 & 0,011 & $-0,255$ & 0,005 \\
\hline X1 & 4,090 & 4,063 & 4,160 & 4,280 & 4,513 \\
\hline X2 & 0,003 & 0,003 & 0,003 & 0,002 & 0,002 \\
\hline X3 & $\mathbf{0 , 3 2 6}$ & $-\mathbf{- 0 , 3 4 0}$ & $-\mathbf{0 , 1 4 8}$ & $\mathbf{0 , 2 3 7}$ & $\mathbf{0 , 2 1 0}$ \\
\hline X-Score
\end{tabular}

Sumber: data sekunder yang diolah kembali oleh penulis

Setelah diperoleh hasil perhitungan seluruh rasio-rasio dari masing-masing analisis kebangkrutan dengan mengolah data berupa laporan keuangan tahunan pada PT Garuda Indonesia, Tbk periode 2014 sampai dengan 2018, maka dapat diketahui hasil dari analisis prediksi kebangkrutan perusahaan yang dapat dilihat pada tabel interpretasi hasil dari masing-masing analisis berikut: 
Tabel 4. Interpretasi Hasil Prediksi Kebangkrutan PT Garuda Indonesia, Tbk

\begin{tabular}{|l|l|l|l|l|l|}
\hline Tahun & 2014 & 2015 & 2016 & 2017 & 2018 \\
\hline Altman Z-Score & 0,859 & 1,382 & 1,144 & 0,906 & 0,922 \\
\hline Prediksi & Distress & Grey Area & Grey Area & Distres & Distress \\
\hline Springate & $-0,267$ & 0,618 & 0,393 & 0,072 & 0,218 \\
\hline Prediksi & Distress & Distress & Distress & Distress & Distress \\
\hline Zmijewski & 0,326 & $-0,340$ & $-0,148$ & 0,237 & 0,210 \\
\hline Prediksi & Safe Area & Distress & Distress & Safe Area & Safe Area \\
\hline
\end{tabular}

Sumber: data sekunder yang diolah kembali oleh penulis

Dalam tabel 4.4 di atas terlihat bahwa hasil prediksi ketiga analisis kebangkrutan tersebut memiliki perbedaan dimana untuk analisis Altman Z-Score pada Garuda Indonesia memiliki kondisi yang kurang baik dan berpotensi bangkrut ditahun 2014, 2017 dan 2018 karena nilai yang diperoleh lebih kecil dari angka cut-off yaitu 1,2. Sedangkan ditahun 2015 dan 2016 kondisi keuangannya mulai membaik hingga naik 52\% namun masuk ke dalam kategori abu-abu atau tidak baik ataupun buruk keadaannya karena nilai yang diperoleh lebih besar dari nilai cut-off bangkrut 1,2 dan lebih kecil dari nilai cut-off tidak bangkrut yaitu 2,9.

Sedangkan untuk analisis Springate menyatakan pada tahun 2014 hingga 2018 semuanya berada dikategori terancam bangkrut, ini terlihat dari nilai yang diperoleh keseluruhan periode menunjukan hasilnya lebih kecil dari angka 0,862 yang merupakan nilai cut-off Springate.

Dan untuk analisis Zmijewski menunjukkan hasil yang berbalik dengan analisis Altman maupun Springate dimana analisis Zmijewski menyatakan Garuda Indonesia pada tahun 2014, 2017 dan 2018 memiliki kondisi yang sehat atau aman dari ancaman bangkrut hal ini dikarenakan nilai yang diperoleh lebih besar dari nilai batas cut-off yakni 0 (nol), sedangkan ditahun 2015 dan 2016 Garuda Indonesia terlihat memiliki nilai yang negatif atau lebih kecil dari batas cut-off Zmijewski.

\section{Analisis Statistik Deskriptif}

Menurut Sugiyono (2017:147-148) statistik deskriptif adalah statistic yang digunakan untuk menganalisis data dengan cara mendiskripsikan atau menggambarkan data yang telah terkumpul sebagaimana adanya tanpa bermaksud membuat kesimpulan yang berlaku untuk umum atau generalisasi. Secara teknis statistik deskriptif diketahui tidak ada uji signifikansi, tidak ada taraf kesalahan, karena peneliti tidak beermaksud membuat generalisasi, sehingga tidak ada kesalahan generalisasi.

Hasil dari analisis potensi kebangkrutan PT Garuda Indonesia, Tbk dengan menggunakan tiga model analisis prediksi kebangkrutan yang kemudian dianalisis statistik deskriptifnya menggunakan SPSS 22, dapat dilihat pada tabel 4.5 yang telah disajikan berikut: 
Tabel 5. Descriptive Statistics

\begin{tabular}{|l|l|l|l|l|l|}
\hline & N & Min & Max & Mean & Std. Dev \\
\hline Altman & 5 & .859 & 1.382 & 1.04260 & .219310 \\
Springate & 5 & -.267 & .618 & .20680 & .334118 \\
Zmijewski & 5 & -.340 & .326 & .05700 & .286271 \\
Valid N (listwise) & 5 & & & & \\
\hline
\end{tabular}

Sumber: data yang diolah menggunakan SPSS22.

Dari tabel statistik deskriptif tersebut dapat diketahui bahwa nilai rata-rata Altman ZScore Garuda Indonesia adalah sebesar 1,043 per tahunnya dengan standar deviasi 0,219 dan nilai minimum yang dimiliki oleh Garuda Indonesia sebesar 0,859 yang dapat dilihat pada tahun 2014, dengan nilai terbesar pada tahun 2015 sebesar 1,382.

Sedangkan nilai rata-rata yang dimiliki Springate S-Score Garuda Indonesia adalah sebesar 0,207 dengan standar deviasinya 0,334. Dan nilai terkecil yang dimiliki oleh Garuda Indonesia sebesar $-0,267$ yang dapat dilihat pada tahun 2014, dengan nilai terbesar sebesar 0,618 pada tahun 2015 .

Dan nilai rata-rata Zmijewski X-Score Garuda Indonesia adalah sebesar 0,057 dengan nilai deviasi sebesar 0,286 . Dengan nilai terkecil yang dimiliki sebesar $-0,340$ yang dapat dilihat pada tahun 2015, dan nilai terbesar berada pada tahun 2014 sebesar 0,326.

\section{SIMPULAN}

Berdasarkan hasil dari pembahasan serta analisis kebangkrutan yang telah dilakukan pada PT Garuda Indonesia (Persero) Tbk, maka dapat diambil kesimpulan bahwa Altman dan Springate sama-sama menyatakan Garuda Indonesia memiliki score yang sangat rendah sehingga dapat dikategorikan ke dalam kondisi yang kurang baik atau sedang terancam bangkrut, berbeda dengan analisis Zmijewski yang menyatakan hasil Garuda Indonesia aman dari ancaman kebangkrutan. Penelitian ini menunjukan bahwa interpretasi dari tiap-tiap analisis prediksi tersebut tidak begitu sensitif perbedaannya, yang mana penggunaan analisis baik metode Altman, Springate maupun Zmijewski menghasilkan tingkat akurasi yang hampir sama. Berdasarkan hasil statistik deskriptif diperoleh hasil yang berbeda dimana terdapat adanya perbedaan pada potensi kebangkrutan Garuda Indonesia yang menggunakan metode Altman Z-Score dengan metode Springate dan Zmijewski, sedangkan untuk metode Springate dan Zmijewski sendiri memiliki rata-rata potensi kebangkrutan yang hampir sama, yakni sama-sama berada dititik nol koma.

\section{SARAN}

Penelitian ini hanya memprediksikan kebangkrutan menggunakan data-data yang diperoleh dari beberapa periode sebelum kebangkrutan terjadi, namun dalam kenyataan, analisis tidak pernah tahu kapan perusahaan yang diteliti tersebut akan benar-benar bangkrut. Berdasarkan keterbatasan pada penelitian ini, maka penulis dapat mengemukakan beberapa saran antara lain:

Perusahaan diharapkan untuk lebih memperhatikan laporan keuangan baik dari total aktiva, laba, kewajiban jangka pendek maupun jangka panjang serta analisis-analisis yang 
akan digunakan dalam pengambilan keputusan. Sehingga ketika kondisi keuangan sedang tidak stabil, perusahaan akan bisa mengetahui masalah dan dapat mengambil keputusan dengan tindakan yang tepat untuk merumuskan perbaikan-perbaikan keuangan perusahaan kedepannya. Perusahaan juga diharapkan agar dapat memperhatikan beban-beban perusahaan, karena semakin besar total kewajiban maka akan semakin besar pula kerugian yang didapat dan mampu membawa ke kondisi yang tidak diinginkan.

Untuk para peneliti selanjutnya, diharapkan untuk menambah alat analisis potensi kebangkrutan lainnya yang telah ditemukan oleh beberapa ahli analisis seperti Ohlson, Grover dll.

\section{DAFTAR PUSTAKA}

Asnawi, Said Kelana dan Chandra Wijaya. 2014. Metodologi Penelitian Keuangan : Graha Ilmu.

Adnan, M. A dan M. Taufik. 2014. Analisis ketepatan prediksi metode Altman terhadap terjadinya likuidasi pada lembaga perbankan. Jurnal Ekonomi dan Auditing Vol 5, No. 2, Desember. Yogyakarta: Fakultas Ekonomi Universitas Islam Indonesia. Yogyakarta.

Dungga, Meriyana Franssisca. 2016. Pengaruh Aset Growth Terhadap Return Saham Pada Perusahaan Real Estate And Property Di BEl. Jurnal Kebijakan Publik Edisi XXV-ISSN 0216454X, April-Juli, 1-4, Dosen FE, Universitas Negeri Gorontalo

Endri. 2017, Prediksi Kebangkrutan Bank Untuk Menghadapi Dan Mengelola Perubahan Lingkungan Bisnis: Analisis Model Altman's Z-Score. Perbanas Quarterly Review, Vol. 2 No. 1, Maret: Universitas Perbanas Surabaya.

Fahmi, Irham. 2010. Manajemen Resiko. Bandung: Alfabeta.

Girlita, dkk. 2015. Analisis Altman (Z-Score) Sebagai Salah Satu Cara Untuk Mengukur Potensi Kebangkrutan Perusahaan (Studi Pada Perusahaan Manufaktur Yang Listing Di BEI Dan Perusahaan Manufaktur Yang Delisting Dari BEI Periode 2012-2014). Jurnal Administrasi Bisnis (JAB), Vol. 25 No. 1. Agustus, Malang: Universitas Brawijaya

Hanafi, Mamduh dan Abdul Halim. 2018. Analisis Laporan Keuangan Edisi 5 Cetakan Kedua. Yogyakarta : UPP STIM YKPN

Hanafi, Mamduh. 2016. Manajemen Risiko Edisi 3. Yogyakarta : UPP STIM YKPN

Harjito, Agus dan Martono. 2014. Manajemen Keuangan Edisi 2 Cetakan Keempat. Yogyakarta : EKONISIA.

Helfert, Erich A. 1997. Teknik Analisis Keuangan Edisi 8. Jakarta : ERLANGGA.

Hery. 2012. Analisis Laporan keuangan. Jakarta: Bumi Aksara.

Husnan, Suad. 2013. Manajemen Keuangan Teori Dan Penerapan (Keputusan Jangka Panjang), Edisi 4. Yogyakarta: BPFE

Munawir. 2002. Akuntansi Keuangan dan Manajemen Edisi 1. Jogjakarta. BPFE

Sjahrial, Dermawan. 2014. Manajemen Keuangan Lanjutan, Edisi Revisi. Jakarta: Mitra Wacana

http://jurnal.stiekma.ac.id/index.php/JAMIN 
Media.

Sugiyono. 2017. Metode Penelitian. Bandung: Alfabeta.

Sutrisno. 2013. Manajemen Keuangan Teori Konsep dan Aplikasi Cetakan 9. Yogyakarta : EKONISIA

Kakauhe, Anastasya Claudio Inri. 2017. Analisis Model Altman (Z-Score) Dalam Mengukur Kinerja Keuangan Untuk Memprediksi Kebangkrutan Pada Perusahaan Manufaktur Sektor Industri Barang Konsumsi Di Bursa Efek Indonesia (BEI) Periode 2010-2014. Jurnal Accountability, Vol. 08 No. 01, 18-27,

Nugroho, Arief Yuswanto. 2018. Model Analisis Z Score Terhadap Prediksi Kebangkrutan (Studi pada PT Garuda Indonesia, Tbk tahun 2015-2017). J-MACC: Journal of Management and Accounting, Vol. 1 No. 2, Oktober: Universitas Islam Darul 'Ulum Lamongan.

Prihanthini, Ni Made Evi Dwi. 2013. Prediksi Kebangkrutan Dengan Model Grover, Altman Z-Score, Springate Dan Zmijewski Pada Perusahaan Food And Beverage Di Bursa Efek Indonesia. EJurnal Akuntansi Universitas Udayana 5.2: 417-435.

Purnajaya, Komang Devi Methili. 2014. Analisis Komparasi Potensi Kebangkrutan Dengan Metode Z-Score Altman, Springate, Dan Zmijewski Pada Industri Kosmetik Yang Terdaftar Di Bursa Efek Indonesia. E-Jurnal Akuntansi Universitas Udayana, 7.1: 48-63.

Rizal, Muhamad. 2017. Analisis Kinerja Keuangan PT. Garuda Indonesia Tbk. Jurnal Serambi Ekonomi dan Bisnis. Vol. 4 No. 1. Universitas Samudra

Safira, Atikah Noora, dkk. 2015. Implementasi Altman's Z-Score Model Untuk Memprediksi Kebangkrutan Perusahaan Multinasional (Studi Pada Perusahaan Multinasional Sub Sektor Tekstil Dan Garmen Yang Terdaftar Di Bursa Efek Indonesia Periode 2011-2014). Jurnal Administrasi Bisnis (JAB), Vol. 27 No. 1. Oktober, Malang: Universitas Brawijaya

Sari, Ika Agustina, dkk. 2017. Analisis Perbandingan Metode Springate Dan Zmijewski Dalam Menilai Kesehatan Keuangan Perusahaan Pertambangan Batubara Di BEI. The 9th FIPA: Forum IImiah Pendidikan Akuntansi - Universitas PGRI Madiun, Vol. 5 No. 1, Hal. 692-702, Oktober, Madiun, e-ISSN: 2337-9723

Syilviana, dan Titiek Rachmawati. 2014. Analisis Kebangkrutan Dengan Menggunakan Model Altman Z-Score Pada Perusahaan Asuransi Yang Go Public Di Bursa Efek Indonesia ( Periode Tahun 2010-2013).

Yuliastary, Etta Citrawati. 2014. Analisis Financial Distress Dengan Metode Z-Score Altman, Springate, Zmijewski. E-Jurnal Akuntansi Universitas Udayana 6.3: 379-389

https://idn.ccb.com/business-financial.html (Sabtu, 26/01/2019, 20:16)

https://www.idx.co.id/ (Sabtu, 26/01/2019, 20:22)

https://media.neliti.com/media/publications/266498-model-analisis-z-score-terhadap-prediksi340a9e7a.pdf (Sabtu, 26/01/2019, 20:22)

http://e-jurnal.unisda.ac.id/index.php/J-MACC/article/view/1184/721 (Sabtu,26/01/2019, 20:22)

http://jurnal.umsu.ac.id/index.php/kumpulandosen/article/view/1296 syilvi titiek,

http://jurnal.stiekma.ac.id/index.php/JAMIN 
https://www.cnnindonesia.com/ekonomi/ (Selasa, 05/03/2019, 14:23)

https://ekonomi.kompas.com/(Selasa, 05/03/2019, 14:29)

https://www.garuda-indonesia.com/id/id/investor-relations/annual-report-dan-sustainabilityreport/annual-report.page (Rabu, 06/03/2019, 20:07)

https://www.idnfinancials.com/GIAA/PT-Garuda-Indonesia-Tbk (Rabu, 06/03/2019, 20:11)

http://e-jurnal.unisda.ac.id/index.php/J-MACC/article/view/1184/721 (Minggu, 17/03/2019, 21.57)

https://elib.unikom.ac.id/files/disk1/539/ibptunikompp-gdl-aldisetiad-26939-4-unikom a-i.pdf (Minggu, 17/03/2019, 21.57)

https://media.neliti.com/media/publications/96684-ID-penggunaan-metode-z-score-untukmempredi.pdf (Minggu, 17/03/2019, 22.10)

http://jurnal.umsu.ac.id/index.php/kumpulandosen/article/view/1296 (Minggu, 17/03/2019, 22.10) 